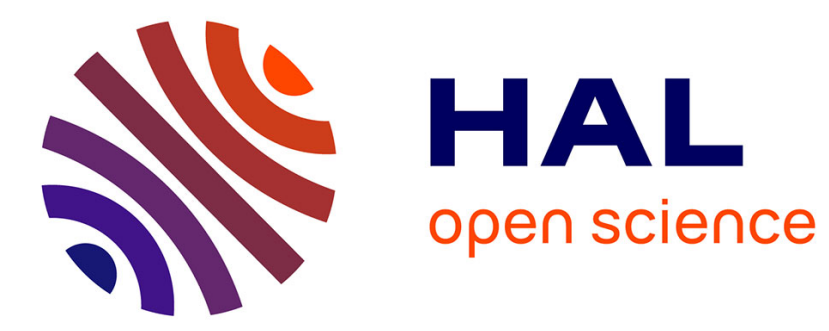

\title{
Highly effective sirolimus therapy for abdominal lymphangioleiomyoma
}

D. Lecuelle, D. Basille, C. Renard, F. Saint, V. Jounieaux

\section{To cite this version:}

D. Lecuelle, D. Basille, C. Renard, F. Saint, V. Jounieaux. Highly effective sirolimus therapy for abdominal lymphangioleiomyoma. Respiratory Medicine and Research, 2019, 75, pp.32 - 34 . 10.1016/j.resmer.2019.02.002 . hal-03486606

\section{HAL Id: hal-03486606 https://hal.science/hal-03486606}

Submitted on 20 Dec 2021

HAL is a multi-disciplinary open access archive for the deposit and dissemination of scientific research documents, whether they are published or not. The documents may come from teaching and research institutions in France or abroad, or from public or private research centers.
L'archive ouverte pluridisciplinaire HAL, est destinée au dépôt et à la diffusion de documents scientifiques de niveau recherche, publiés ou non, émanant des établissements d'enseignement et de recherche français ou étrangers, des laboratoires publics ou privés.

\section{다)(1) $(5$}

Distributed under a Creative Commons Attribution - NonCommerciall 4.0 International 
Title: Highly effective sirolimus therapy for abdominal lymphangioleiomyoma

\section{$\underline{\text { Authors names and affiliations: }}$}

Damien Lecuelle ${ }^{1}$; Damien Basille, $\mathrm{MD}^{2}$; Cedric Renard, $\mathrm{MD}^{3 ;}$ Fabien Saint, MD-PhD ${ }^{1,4,5}$ and Vincent Jounieaux, MD-PhD ${ }^{2}$.

\section{$\underline{\text { Department(s) and institution(s) }}$}

1. Departments of Urology and Transplantation, University Hospital AmiensPicardie, 80054 Amiens Cedex 1, France.

2. Department of Respiratory Diseases and Intensive Care Unit, University Hospital Amiens-Picardie, 80054 Amiens Cedex 1, France.

3. Department of Radiology, University Hospital Amiens-Picardie, 80054 Amiens Cedex 1, France.

4. Research Laboratory EPROAD (EA 4669), University Picardie Jules Verne, 80000 Amiens, France.

5. Biobanque de Picardie, University Hospital Amiens-Picardie, 80054 Amiens Cedex 1, France.

\section{Corresponding author: Damien Basille}

Department of Respiratory Diseases and Intensive Care Unit

University Hospital Amiens-Picardie

80054 Amiens Cedex 1

France

Email: basille.damien@chu-amiens.fr

Phone: 0033-322-45-59-10

Fax: 0033-322-45-60-59

$\underline{\text { Key words: }}$ Sirolimus; TOR Serine-Threonine Kinases; Lymphangioleiomyomatosis

\section{Declarations of interest: none}

Funding sources: This research did not receive any specific grant from funding agencies in the public, commercial, or not-for-profit sectors.

\section{Total number of pages: 7}


Total number of photographs: 1

Word counts: 780

\section{Contribution Details:}

$\begin{array}{ccccc}\text { LECUELLE } & \text { BASILLE } & \text { RENARD } & \text { SAINT } & \text { JOUNIEAUX } \\ \text { Damien } & \text { Damien } & \text { Cedric } & \text { Fabien } & \text { Vincent }\end{array}$

$\begin{array}{lccccc}\text { Concepts } & \text { X } & \text { X } & \text { X } & \text { X } & \text { X } \\ \begin{array}{l}\text { Literature } \\ \text { search }\end{array} & \text { X } & \text { X } & \text { X } & \text { X } & \text { X } \\ \begin{array}{l}\text { Data } \\ \text { acquisition }\end{array} & \text { X } & \text { X } & \text { X } & \text { X } & \text { X } \\ \begin{array}{l}\text { Manuscript } \\ \text { preparation }\end{array} & \text { X } & \text { X } & & \text { X } & \text { X } \\ \begin{array}{l}\text { Manuscript } \\ \text { review }\end{array} & \text { X } & \text { X } & \text { X } & \text { X } & \text { X }\end{array}$




\section{Main Text:}

Pulmonary lymphangioleiomyomatosis (P-LAM) is a rare interstitial lung disease characterized by cystic lesions in the lung parenchyma. Extrapulmonary lymphangioleiomyomatosis usually affects the kidneys with the formation of angiomyolipomas, but is rarely associated with intra-abdominal lesions such as retroperitoneal lymphangioleiomyoma [1].

We report the case of a 35-year-old woman with a 10-month history of progressive dyspnoea. In 2015, lung CT revealed multiple thin-walled lung cysts evenly distributed throughout the lungs with normal lung parenchyma and enlarged mediastinal lymph nodes $(>1 \mathrm{~cm})$ consistent with P-LAM (Figure 1). Abdominal CT visualized a large hypodense retroperitoneal mass consistent with lymphangioleiomyoma (Figure 1). Pulmonary function tests demonstrated a severe obstructive pattern and decreased exercise performance with exercise desaturation. Forced expiratory volume in one second $\left(\mathrm{FEV}_{1}\right)$ was initially $1.63 \mathrm{~L}$ ( $47 \%$ of predicted) with a $\mathrm{FEV}_{1} / \mathrm{VC}$ ratio of $51 \%$. Considering the typical chest imaging and abdominal lymphangioleiomyoma, a definitive diagnosis of lymphangioleiomyomatosis was established according to the ERS Guidelines 2010 [1]. The diagnosis was confirmed by elevation of VEGF-D levels to $4000 \mathrm{pg} / \mathrm{mL}$ [2]. Following a multidisciplinary staff meeting, sirolimus was initiated at a dose of $2 \mathrm{mg} / \mathrm{day}$ and then progressively increased to $5 \mathrm{mg} / \mathrm{day}$. Therapeutic drug monitoring was performed to obtain a therapeutic level between 8 and 12 $\mu \mathrm{g} / \mathrm{L}$. No serious side effects were observed. Pregnancy was contraindicated and oestrogenfree contraception was initiated. Six months after initiating sirolimus therapy, a significant improvement of pulmonary function tests was observed with a $670 \mathrm{~mL}$ increase in $\mathrm{FEV}_{1}$ (2.27 L, 66\% of predicted), but exercise desaturation and dyspnoea remained unchanged. After 14 months of sirolimus therapy, no improvement was observed on lung CT, whereas abdominal CT showed a significant reduction of the volume of the retroperitoneal lesion (70\% 
reduction of the volume of the target lesion) (Figure 1). At 30-month follow-up, the improvement of pulmonary function tests remained stable and the abdominal lymphangioleiomyoma had completely disappeared.

Lymphangioleiomyomatosis occurs sporadically or in association with tuberous sclerosis complex, a genetic disease [1]. Tuberous sclerosis complex is caused by germline mutations of either TSC1 or TSC2 gene. Both genes are tumour suppressor genes encoding hamartin (TSC1) and tuberin (TSC2). Inherited mutations of the TSC-1 or TSC-2 genes have recently been shown to be the cause of tuberous sclerosis complex, while acquired (somatic) mutations of either gene are associated with sporadic lymphangioleiomyomatosis, resulting in constitutive activation of the kinase mammalian target of rapamycin (mTOR). As in our case report, lymphangioleiomyomatosis usually affects women of childbearing potential and oestrogens likely play a fundamental role in disease progression. Some reports have suggested that oestrogen administration or pregnancy may accelerate disease progression [3].

Pulmonary manifestations of lymphangioleiomyomatosis usually consist of thin-walled lung cysts distributed throughout the lungs, mediastinal lymphadenopathy and/or chylous pleural effusion. Pulmonary function tests frequently show an "obstructive" or "mixed" pattern [3]. As observed in the present case, $24 \%$ to $77 \%$ of cases of lymphangioleiomyomatosis present abdominal abnormalities including renal angiomyolipomas, abdominal lymphadenopathy, lymphangioleiomyomas and/or chylous ascites [4]. Abdominal manifestations mimicking retroperitoneal tumours may precede the diagnosis of pulmonary lymphangioleiomyomatosis, leading to delayed diagnosis [4,5]. Abdominal lymphangioleiomyoma is a rare manifestation of lymphangioleiomyomatosis, usually occurring in the upper retroperitoneal area close to the abdominal aorta and/or pelvic cavity according to the anatomical distribution of lymphatic vessels [5]. 
Sirolimus is now recommended as treatment for patients with lymphangioleiomyomatosis with abnormal/declining lung function or symptomatic chylous fluid accumulations [2,6-8]. Taveira-DaSilva et al. enrolled patients with chylous pleural effusions and other lymphatic manifestations of lymphangioleiomyomatosis in an open-label, uncontrolled trial [9]. Twelve patients with chylous fluid accumulations were treated with sirolimus. All patients obtained complete or near-complete resolution of their chylous fluid accumulations and presented improvement or stabilization of lung function. We observed a similar benefit of sirolimus on lymphangioleiomyoma with a dramatic reduction in size, which was maintained in our patient with complete disappearance of the abdominal lymphangioleiomyoma after 30 months of sirolimus therapy. Compared to previous studies, we observed an unusual marked improvement of lung function. As shown by Argula et al., this improvement may be partly explained by the effect of sirolimus on proliferating smooth muscle cells in small airways [10]. By reducing cell infiltration in the small airways, sirolimus may relieve airflow obstruction and reduce gas trapping, leading to increased lung compliance.

In the present case report, sirolimus appeared to be highly effective for both pulmonary lymphangioleiomyomatosis and abdominal lymphangioleiomyoma. In the latest guidelines, sirolimus is now recommended for patients with lymphangioleiomyomatosis with abnormal/declining lung function [2]. Sirolimus therapy has also been proposed in patients with symptomatic chylous fluid accumulations prior to invasive management. However, this recommendation is based on very low-quality evidence and additional prospective clinical trials of mTOR-based treatment in patients with lymphangioleiomyomatosis are warranted. 


\section{$\underline{\text { References }}$}

[1] Johnson SR, Cordier JF, Lazor R, Cottin V, Costabel U, Harari S, et al. European Respiratory Society guidelines for the diagnosis and management of lymphangioleiomyomatosis. Eur Respir J 2010;35:14-26. doi:10.1183/09031936.00076209.

[2] McCormack FX, Gupta N, Finlay GR, Young LR, Taveira-DaSilva AM, Glasgow CG, et al. Official American Thoracic Society/Japanese Respiratory Society Clinical Practice Guidelines: Lymphangioleiomyomatosis Diagnosis and Management. Am J Respir Crit Care Med 2016;194:748-61. doi:10.1164/rccm.201607-1384ST.

[3] Hohman DW, Noghrehkar D, Ratnayake S. Lymphangioleiomyomatosis: A review. Eur J Intern Med 2008;19:319-24. doi:10.1016/j.ejim.2007.10.015.

[4] Chu SC, Horiba K, Usuki J, Avila NA, Chen CC, Travis WD, et al. Comprehensive evaluation of 35 patients with lymphangioleiomyomatosis. Chest 1999;115:1041-52.

[5] Matsui K, Tatsuguchi A, Valencia J, Yu Z x, Bechtle J, Beasley MB, et al. Extrapulmonary lymphangioleiomyomatosis (LAM): clinicopathologic features in 22 cases. Hum Pathol 2000;31:1242-8.

[6] Bissler JJ, McCormack FX, Young LR, Elwing JM, Chuck G, Leonard JM, et al. Sirolimus for angiomyolipoma in tuberous sclerosis complex or lymphangioleiomyomatosis. N Engl J Med 2008;358:140-51. doi:10.1056/NEJMoa063564.

[7] Yao J, Taveira-DaSilva AM, Jones AM, Julien-Williams P, Stylianou M, Moss J. Sustained effects of sirolimus on lung function and cystic lung lesions in lymphangioleiomyomatosis. Am J Respir Crit Care Med 2014;190:1273-82. doi:10.1164/rccm.201405-0918OC.

[8] McCormack FX, Inoue Y, Moss J, Singer LG, Strange C, Nakata K, et al. Efficacy and safety of sirolimus in lymphangioleiomyomatosis. N Engl J Med 2011;364:1595-606. doi:10.1056/NEJMoa1100391.

[9] Taveira-DaSilva AM, Hathaway O, Stylianou M, Moss J. Changes in lung function and chylous effusions in patients with lymphangioleiomyomatosis treated with sirolimus. Ann Intern Med 2011;154:797. doi:10.7326/0003-4819-154-12-201106210-00007.

[10] Argula RG, Kokosi M, Lo P, Kim HJ, Ravenel JG, Meyer C, et al. A novel quantitative computed tomographic analysis suggests how sirolimus stabilizes progressive air trapping in lymphangioleiomyomatosis. Ann Am Thorac Soc 2016;13:342-9. doi:10.1513/AnnalsATS.201509-631OC. 


\section{Figure legends:}

Figure 1: Chest CT (a, b) and abdominopelvic CT (c, d) before sirolimus therapy showing multiple thin-walled lung cysts and a large abdominal lymphangioleiomyoma $(86.5 \mathrm{~mm}$ in longest diameter on the axial view). Chest CT (e,f) and abdominopelvic CT (g,h) after 14 months of sirolimus therapy showing significant reduction of the volume of the retroperitoneal lesion $(25 \mathrm{~mm}$ in longest diameter on the axial view). 

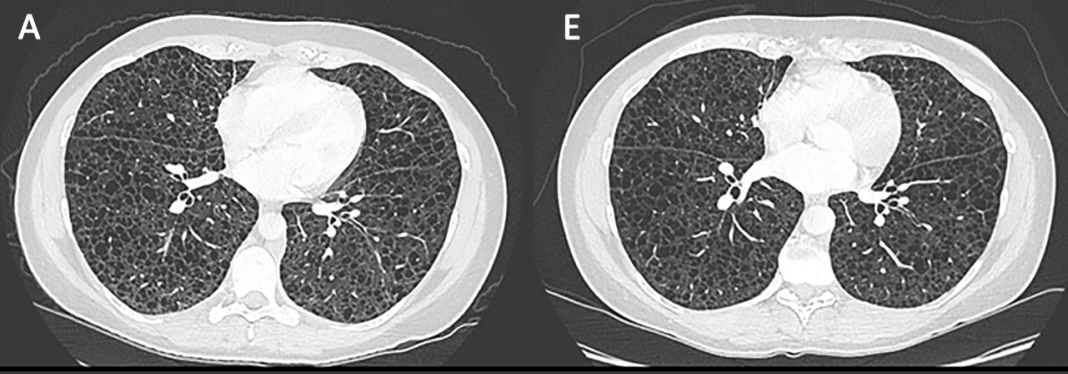

B

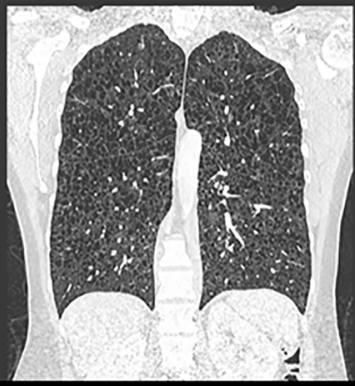

F

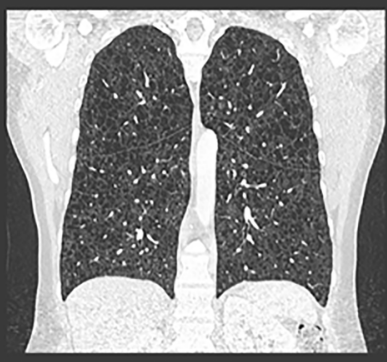

C

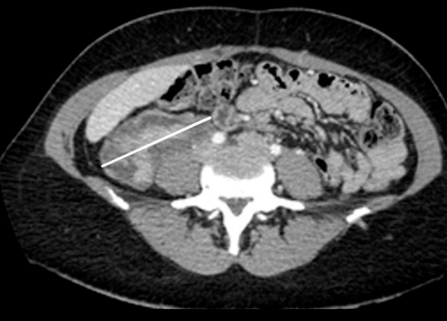

D

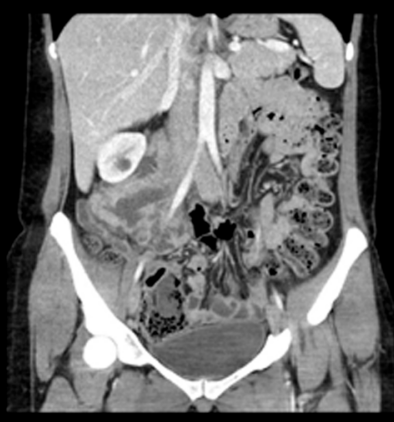

G

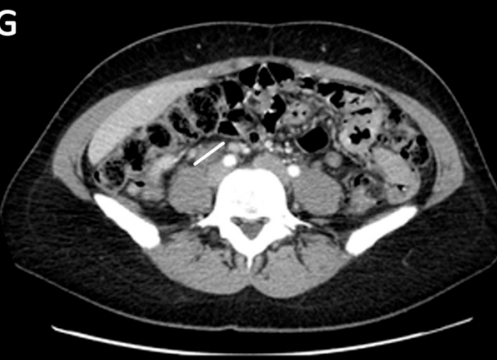

H

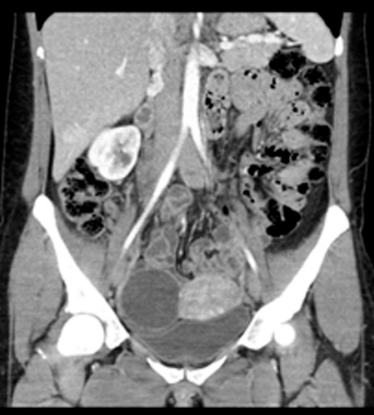

